\title{
ENGINEERING GEOLOGICAL PROBLEMS ASSOCIATED WITH KARST TERRAINS: THEIR INVESTIGATION MONITORING, AND MITIGATION AND DESIGN OF ENGINEERING STRUCTURES ON KARST TERRAINS
}

\author{
G.S. Xeidakis ${ }^{1}$, A. Torok ${ }^{2}$, S.Skias ${ }^{1}$ and B. Kleb ${ }^{2}$ \\ ${ }^{1}$ Department of Civil Engineering, Democritus University of Thrace, 67100, Xanthi, Greece. \\ ${ }^{2}$ Department of Engineering Geology and Engineering Materials, Budapest University of \\ Technology and Economics, H-1521, Budapest, Hungary.
}

\begin{abstract}
The design and construction of civil engineering structures in karst regions confronts many problems due to unpredictable location, dimensions and geometry of the karst structure and voids. Karst terrain is one of the most intricate grounds to be assessed for civil engineering purposes. Conventional methods of site exploration like desk studies, site reconnaissance, borings, test pits, geophysical techniques, have their advantages and disadvantages; none of them are $100 \%$ accurate; therefore they should be used in concert, adapted to each project, the available budget and the undertaken risk. As not two sides are identical in karst, site investigation should be tailored to each site. Factors that should be considered when designing site investigation in karst are: maturity of karst landforms, depth of the karst features, overburden thickness, lateral extent of the karst features, hydrogeology of the area, laoding, etc.

The main problems confronted by engineers designing structures on or in karst terrain are: difficulties in excavation and grading the ground over pinnacled rockheads; collapse of the roof over subsurface voids, subsidence of cover soil over sinkhole, difficulties in founding a structure over an irregular or pinnacled rockhead, loss of water from dam reservoirs, pollution of groundwater, etc. A number of solutions have been practiced by engineers to solve these problems like: relocating the structure on a safer site, filling the voids and the fractures with concrete, improving the foundation ground with grouting and/or geogrids, replacing foundation soil, bridging the voids with rigid mats or beams, using deep foundations (piling, drilled shafts, etc.), minimizing future sinkhole development by controlling surface and ground water, etc.
\end{abstract}

\section{SITE INVESTIGATION ON KARST TERRAIN}

A Karst terrain consists one of the most difficult ground conditions that have to be evaluated for civil engineering purpose. Conventional methods like: thorough data review, to obtain as much information as possible, including topographic and geologic maps, air photos, sinkholes maps, hydrogeology reports, water well records, and previous test boring information, are useful but not enough. These sources should be used to provide an indication of existence of caves, sinkholes and disappearing streams, faulting, rock quality, depth of overburden, and well yields which might foretell the degree of dissolution or fracturing of the rock. Investigation should be followed by site reconnaissance, by experienced personnel, to verify and extend the findings of the preliminary (desk) site evaluation. This stage should also include interviews with persons familiar with the site. The subsurface investigation program, that follows, should maximize the data obtained with a reasonable effort and cost, using various exploration techniques such as test boring, test pits, air track probes, georadar and geophysical surveys (resistivity, microgravity, electromagnetic, seismic refraction, etc). 


\subsection{Reliability of methods}

Conventional practices show that the aforementioned methods may be adequate for investigation in karst sites of classes kl and kll, i.e. for simpler cases. Sites with more mature karst (classes $\mathrm{kIII-kV}$ ) demand more rigorous ground investigations, managed by a multidisciplinary team that fully appreciates the complex characteristics of karst. No two karst sites are exactly alike in topography and geology, and no method is 100\% accurate. Each site may require the use of different combination of investigation methods. A major difficulty in karst is locating subsurface voids.

Table 1 shows the estimated reliability of the various investigation methods from a sinkhole investigation project, carried out in karst region in eastern Pennsylvania and northern New Jersey, USA. In that project 12 site investigation companies took part, applying the 12 most commonly used site investigation methods. The findings were statistically processed and the results of their reliability in detecting existing sinkholes and subsurface voids (caves) are presented in Table 1.

Table 1. Estimated reliability of the various site investigation methods for detecting sinkholes and caves in karst terrain (in Thomas and Roth, 1999)

\begin{tabular}{lll}
\hline Method & $\begin{array}{l}\text { Reliability associated with } \\
\text { finding existing sinkholes }\end{array}$ & $\begin{array}{l}\text { Reliability associated with } \\
\text { finding subsurface voids }\end{array}$ \\
\hline $\begin{array}{l}\text { Borings/air track drilling/cone } \\
\text { penetrometer }\end{array}$ & NA (not applicable) & Poor to very good \\
Area reconnaissance & Good to very good & Poor \\
Review of existing mapping & Fair to good & Poor to fair \\
Review of aerial photographs & Fair to very good & Poor \\
Resistivity survey & NA & Poor to fair \\
Seismic refraction survey & NA & Poor \\
Electromagnetic survey & NA & Poor to fair \\
Ground penetrating radar & NA & Poor to fair \\
Trenching & NA & Fair to good \\
Microgravity survey & NA & Poor to fair \\
Video televiewer & NA & Fair to good \\
Borehole to borehole tests/ & NA & Fair to very good \\
tomography & N &
\end{tabular}

As it is shown in Table 1 none of the methods employed has a good applicability for detecting both sinkholes and subsurface voids. Some arte better for the first and some for the second. In the following paragraph the fore and pro of each method is discussed shortly.

\subsection{Brief description of the various methods}

\subsubsection{Probing (boring, air track drilling, cone penetration, etc.)}

The reliability of these methods to locate an existing subsurface void is related directly to the number of probes made and the size of the void. If each probe is completed to the bedrock surface, the probability of locating a void in the ground was estimated by Beacher, et all, 1980, (in Thomas and Roth 1999) to be:

$$
P_{r}=1-\left(1-A_{a} / A_{s}\right)^{n}
$$

where $P_{r}=$ probability of detection of a void, $n=$ number of probes, uniformly distributed over an area $A_{s}$ and $A_{a}=$ horizontal cross sectional area of the void itself.

It has been estimated statistically that a density of 2500 probes per hectare is needed to have $90 \%$ chance to locate one void $2.5 \mathrm{~m}$ in diameter in the ground. For example, in Belgium for the construction of a viaduct on class kIII karst, 31 boreholes had opened for five pier sites finding no subsurface void; during the excavation for foundation of the piers two caves were located. A second phase of 308 probes for investigation of the broader area found no more caves (Waltham, et al 1988, in Waltham and Fookes, 2003). This example shows the difficulty of locating voids in the ground by probing. It also shows that the true ground conditions in karst are discovered only after foundations are excavated. In general, 3-5 probes beneath every pile foot and column base are probably the best option in karst classes kl-kIII and are essential at pinnacled rockhead in classes kIV-kV karst. 
Depth of probing: The depth of probing is a function of void size and its depth. Waltham and Fookes 2003 recommended that in karst of classes $\mathrm{kl}$ to $\mathrm{kIII}$, in their karst classification, caves more than $5 \mathrm{~m}$ wide are unusual, and probing of $3.5 \mathrm{~m}$ in depth should be satisfied. Concerning the depth of probing, inside bedrock beneath pile tips, engineering practice varies considerably from $2 \mathrm{~m}$ in North Carolina karst, up to $5 \mathrm{~m}$ in cavernous Florida karst and $4 \mathrm{~m}$, under foundations, in South Africa (in Waltham and Fookes 2003); some of the boreholes should be inclined up to $15^{\circ}$.

Tunneling: Probing is also necessary during tunnel excavation in karstified limestone; 3-5 boreholes, 10-12 m deep, should be drilled to the rock, from the face of the tunnel, in advance of the excavation cycle to check for voids or excess groundwater (Marinos 2001, in Beck et al, 2001).

\subsubsection{Review of existing maps and aerial photographs}

Review of existing maps (topographic, geologic, sinkhole inventory, hydrogeology maps, and aerial photographs), provide a fair to good means to detect surface karst features like sinkholes; however their use for locating subsurface voids are quite limited and need much experience from the user.

\subsubsection{Field reconnaissance}

Visual inspection of the site, on the ground or from the air, is a good practice in locating existing sinkholes and previously filled sinkholes. Heavy vegetation may limit the effectiveness of the method. It cannot be used to locate existing subsurface voids which have no surface features.

\subsubsection{Geophysical methods}

Geophysical methods (resistivity, seismic refraction, microgravity, magnetic, GPR, etc.) on karst have not produced consistently reliable results, so far. However technology is advancing and there are geophysical methods that can produce useful results in certain situations. For example, resistivity surveys have shown to perform better in detecting subsurface voids than electromagnetic surveys, if abrupt changes in topography and man made subsurface objects are present. However their reliability is fair to poor in areas with highly irregular soil-bedrock surfaces. In general, the reliability of resistivity surveys is fair to good for rockhead profiling in classes kl-klll, in Waltham and Fookes 2003 classification, but its reliability in pinnacled rockheads of classes kIV-kV is poor.

Resistivity tomography combined with microgravity can be used to identify rockhead and distinguish buried sinkholes from caves, but it is still quite expensive. Microgravity can recognize missing mass within the ground and produce good data with increasing sophistication of their analysis. For example, Fourier analysis of microgravity data from a grid with spacing of $2 \mathrm{~m}$ can locate caves up to one meter across at specific depths (in Waltham and Fookes 2003). Wider grids cover larger areas and can distinguish low density fills in buried sinkholes, but the analysis is still quite cumbersome.

Seismic methods (refraction, reflection, etc), measure the velocity of compression waves, traveling through the ground. Wave velocity decreases in more fissured and more cavernous ground and thus can be correlated with engineering classification of rock mass. In the future, they may be used to characterize karst classes. So far, seismic methods are most effective in locating boundaries between strata and the interface of soil-rockhead. The methods seldom can locate, even large, cavities in the overburden from the ground surface, because the shock waves through the cover soil travel faster than through the cavities. However, the use of cross-hole seismic methods is possible to locate subsurface voids. In this case, data can be analyzed by computer using tomography to construct two and three dimensional representations of the anomalies. The technique is usually restricted to critical location at the site, due to the high expense of the closely spaced boreholes, the multible shocks needed, and the volume of data to be processed by the computer (Sower, 1996, p.110).

Ground penetrating radar (GPR) emits high-frequency electromagnetic waves traveling through the ground and producing high resolution profiles of subsurface strata. Due to high attenuation of the electromagnetic energy, as it penetrates the ground, its use is limited to shallow depths $(<5 \mathrm{~m})$. Specifically, the depth of penetration and resolution quality is decreasing as the percentage of clay increases in the soil. Static Penetration Test (SPT) has been used sometimes to detect potential sinkhole failure with limited success.

In conclusion geophysical surveys are good for reducing the investigation cost by identifying drilling sites but all geophysical anomalies require verification by drilling. 


\subsubsection{Trenching}

Test pits or trenches are highly reliable for local studies at shallow depths, but they are impractical for greater depths $(>5 \mathrm{~m})$ or below water table; they are expensive for large areas, as well.

\section{DESIGN OF ENGINEERING STRUCTURES' FOUNDATIONS ON KARST TERRAIN}

Once the subsurface exploration has been completed and the earthwork and design parameters of the structure determined, a risk assessment of the site should be made as an integral part of the design of the structure. This should include an overall qualitative assessment of the probability (low, moderate, high) of future subsidence occurrence in the site. The client should also be informed about the risk of his property from future subsidence ( $\mathrm{Hu}$, et al 2001, Destephen and Wargo 1992). The design professionals must be prepared to provide foundation alternatives so as to reduce or eliminate risk. These alternatives, in general, are: regular shallow spread footings with or without soil improvement, rigid mats and grade beams, and deep foundations (piles and piers).

\subsection{Foundations over karst rockhead}

In karst class $\mathrm{kl}$ and $\mathrm{kII}$, the rockhead is usually sound, except for some unpredictable isolated fissures and shallow caves. They, usually, create only minor problems to foundations of structures. Regular spread footings are, principally, sufficient for foundation of ordinary buildings. Installation of piles may be required in some parts of a site and reinforced (grated) beams can be designed to span small new voids (Fisher and Canace, 1989, Destephen and Wargo, 1992, Beck and Herring 2001, Waltham and Fookes 2003, Wagener 1985, etc.).

In class klll karst, rigit rafts and/or grade beams may bridge cavities in the ground (Sowers 1996, Beck, et al., 2001, 1999, 1997, 1995, 1989, 1986, Green, et al, 1995). Mats or preparatory grouting are preferred in Florida, USA, over new sinkholes. Heavy geogrid can be used, as well, to reinforce the soil over voids and reduce the impact of any future catastrophic void collapse. Grouting may be employed to fill fractures and small voids in rockhead, before founding on spread footings within the soil profile; this may be more economical than piling to rockhead.

Compaction grouting through boreholes has been used, as well, in Pennsylvania, USA, for soil improvement (Reith, et al 1999). Grade beams are sometimes applied to bridge any small soil subsidence that could occur with time. These beams are often extended beyond the structure's ends to prevent settlement from subsidence at the building corner (Destephen, et al 1992).

In pinnacled rockheads of karst classes $\mathrm{kIV}$ and $\mathrm{kV}$ deep foundations are used, ending on sound rock. Drilled shafts (caissons) are preferred to piles because piles (both driven and auger cast) may be doglegged (deflected) on pinnacles or deviate on sloped rock and it is difficult to discern their actual bearing capacity (Figure 1). Each pile or shaft tip is probed by 2-3 boreholes to ensure lack of voids beneath its end; some of the boreholes must be inclined (splayed) to $15^{\circ}$ from the vertical to examine the ground surrounding the pile tip. As a guide for planning, the mean final length of end bearing piles should be about $30 \%$ greater of the mean rockhead depth, into the sound bedrock (see Sowers 1996, Waltham and Fookes 2003, p. 114).

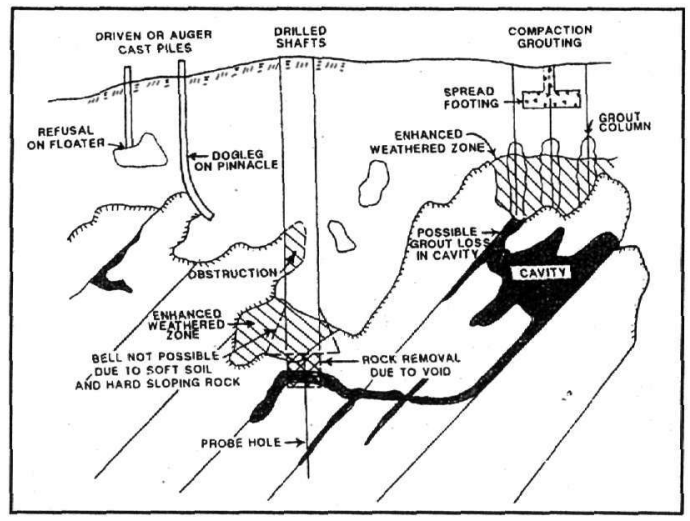

Figure 1. Various types of foundations in karst terrain. (after Destephen and Wargo 1992) 
Although drilled shaft or pile foundations can be designed with virtually no risk of subsidence problems, they are generally very expensive and prohibited for relatively small buildings. Some of the expense will be for reinforced (grade) beams, if the floor slab is structurally supported to span between sound pinnacle tops. The most cost-effective bored piles or shafts are the belled drilled shafts in which the load can be carried by an expanded bearing area formed by a belling tool. This minimizes the shaft diameter, reducing concrete volume. Unfortunately drilled shafts or piles cannot always be successfully belled in karst areas due to perched groundwater, soft overburden soil prone to caving or sloping bedrock (Destephen and Wargo 1992).

Rockhead pinnacles, some $50 \mathrm{~m}$ high, encountered in some tropical karsts, consist a nightmare for founding heavy structures that demand foundations on bedrock. Each pile location requires its own ground investigation and design considerations.

Gypsum has low strength, thus it cannot support high loads of rockhead pinnacles nor heavily loaded end bearing piles.

Roads and light structures pose not much difficulty in founding on soil over a deeply pinnacled rockhead of class KIV-KV.

\subsection{Foundations over caves}

\subsubsection{Generalities.}

Subsurface voids in karst are unpredictable. Every site in such terrain has to be assessed individually in the context of its geology and geomorphology. The design of engineering structures in karst with caves must respond to the local conditions. Local maps and records may indicate typical and maximum possible cave size; local people may also know the larger caves in the area. The maximum size of a cave defines the minimum thickness of sound rock cover needed and the possible depth of probing (Figure 1). The more mature the karst, the larger its caves. There are of course, exceptions to this rule. Fortunately, the karst processes are very slow, compared to effective life of human structures (50-100 years). Therefore if there is not immediate collapse of a void during construction or loading, the danger of future collapse is limited. For example in Slovenia karst voids discoveries and collapses are common during road construction, but subsequent collapses under road operation are very rare (Sebela, et al 1999, Jennings, 1966).

Caves $10 \mathrm{~m}$ across are typically found in karst class kIV but can occur in less mature karst of class klll or even in class kll, as well. In more mature karst (class kV) larger caves are quite common. Many large caves at shallow depths, have entrances open to ground surface and can be visited and assessed by direct observation (e.g. Piges cave in Drama, Alistrati cave in Serres, Diross cave in Mani, and many others in Greece and elsewhere).

\subsubsection{Methods of foundations design on caves}

If caves are critical to planned foundations they are filled with concrete or bridged with graded beams or slabs. Considerable loss of ground may occur during grouting a cave at shallow depth due to flowage into neighboring karst voids or water flow inside the cave; this will increase the foundation cost. To avoid this situation, perimeter grout curtains with thicker grout can be used. Relocation of footings or of the whole structure, when possible, may be proved to be more economical in some cases.

Drilled piles or shafts should be preformed or cast in geotextile sleeves and founded on solid rock at the cave bottom. The cost of such piles may be greater than filling the cave with grout when it is small enough; this is due to inability of dewatering, additional boring needed, depth to rock where troughs occur and rock excavation performed, owning to unsuitable bearing surfaces such as sloping rock, mud seams, voids and weathered zone.

Grout filling in gypsum caves is inappropriate because the greater dissolution rates of gypsum allows the excavation of a new cavity around the concrete plug, within the life time of an overlying engineered structure (Figure 2).

\subsection{Foundation over sinkholes}

A number of viable foundation support solutions exists that help to confront the problem of placing structures over soil with sinkholes and karst voids. The two most commonly used methods are excavation and back filling of the sinkhole, and load transfer to sound rock by bridging or piling. The simplest but not necessarily the most economical solution is to excavate the sinkhole soil to rock and backfill it with a sand and gravel mix and cement grout. If the cavity at the bottom of the 
sinkhole, is large, the throat can be blocked (choked) with a graded rock fill which can be sealed with thick grout and/or layers of impermeable soil fill (clay). The area is then returned to grade with a compacted, impervious material and sealed with geomembrane to prevent future water infiltration. The other solution is the installation of drilled piles or shafts to sound rock strata, as described before (figure 1,3 ).
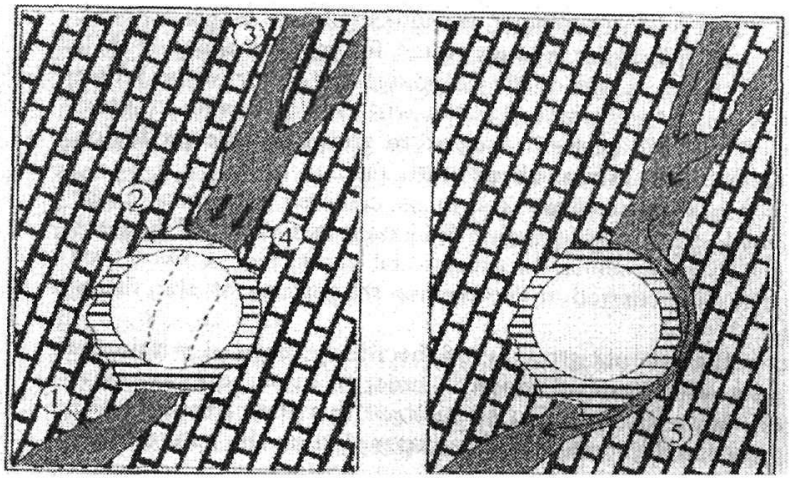

Figure 2. When blocking a big karstic underground water conduit by tunneling or concrete, water may open a new pipe around the block. This is more common practice in gypsum. (after Milanivic, 2000 , in Marinos 2001.

In order to prevent the sinkhole collapse, the key factor is the proper control of water flow at the ground surface and through soil. Downwards percolation of water should be minimized or eliminated, if possible. Sources of potentially dangerous water flows include water from parking and roadway areas, roof down-spouts, catch basins, flow along utility lines, backfills, cultivated areas and irrigated gardens, runoff from impervious surfaces, etc. (Fisher and Canace 1989, Destephen and Wargo 1992, Sowers 1996, Waltham and Fookes 2003, Kannan 1999, Beck et al 1999, ch. 4). Control of water abstraction and lowering the water tables in the area is also critical, especially where the water table is close above rockhead; the water table should always be kept above rockhead.

(a)

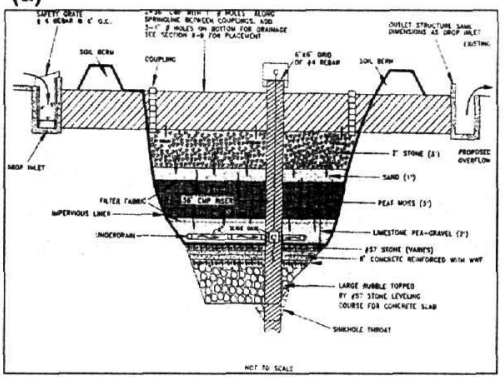

(b)
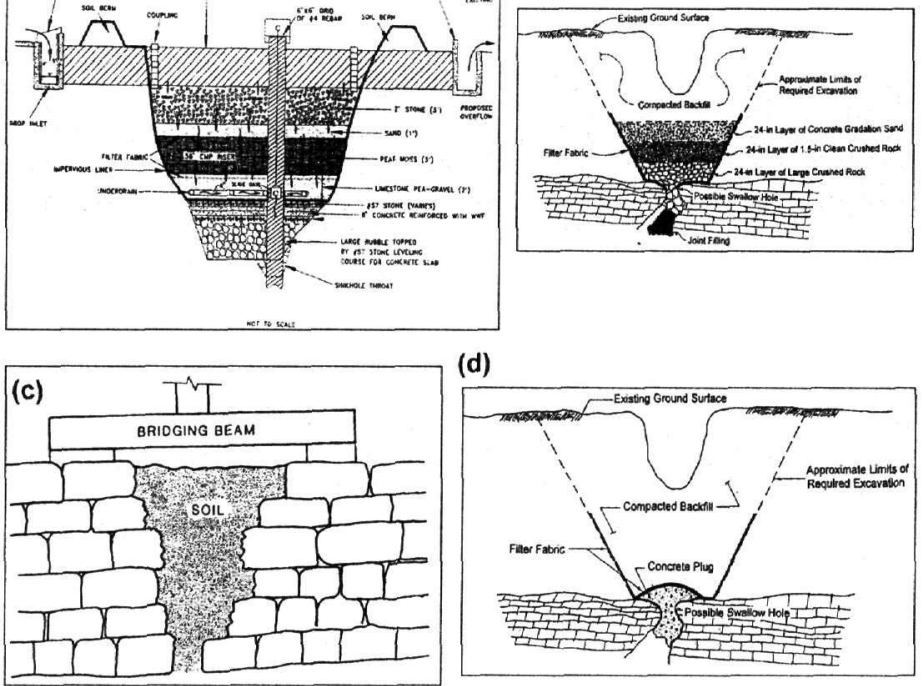

(d)

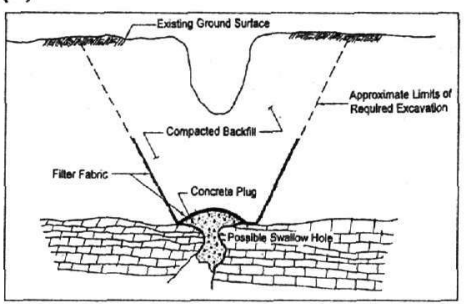

Figure 3. Foundations over sinkholes (a) Excavation and filling with graded materials plus graded beam and drainage, in a highway pavement in Tennessee, USA (Stephenson et al 1997), ((b) Excavation and filling with graded drain material (In Beck et al 1997, p180) (d) Structural plug of the sinkhole throat (Ripp and Baker 1997, in Beck et al 1997, p296) and (c) Bridging with a graded beam (Sowers 1996) 
A good example is Florida's Disney World which stands on 20-30 m of soil over soft, karstified limestone of class kIII, with many sinkholes. They managed to avoid sinkhole subsidence by closely monitoring pumping from water wells and keeping the water table more or less at constant elevation. The pumping is switched off where local water table decline is detected (in Waltham and Fookes 2003). Dewatering by quarrying or tunneling should be banned in karst areas (Marinos 2001, in Beck et al, 2001).

Other measures for remediation and prevention of sinkhole failures are grout sealing at rockhead fissures. This may be applied to karst class kII and kIII, but it is problematic in class kIV and $\mathrm{kV}$ with large pinnacles. In the last case "cap grouting" may be required with cement slurries, after plugging open fissures below.

Compaction grouting, using a low slump grout (slump $<25 \mathrm{~mm}$ ) under pressure, to displace and consolidate soft zones, can be used above groundwater table. The grout forms within the soil a solid block that bridges over fissures and pinnacles. As grout flows in uncontrollable way its placement may not be so effective. Grout columns are sometimes used to improve soil conditions at soil-rock contact (Figure 1,3). Pressure grouting is not recommended "to fill all voids" since the flow and the losses of the grout are uncontrollable.

Deep dynamic compaction for densifying soil, by dropping big weights from a height, is controversial. The method may reduce the permeability of the soil and collapse soil-rock cavity roofs, but if it fails to do so, it may increase the potential of future void roof collapse (Destephen et al 1992).

In karst of class kll-kIV, sinkhole hazard can be reduced by laying geogrid into the soil combined with proper drainage control (Villard, et al 2000).

\section{TUNNELING IN KARST}

Tunneling in karstic environment is confronted with two main problems: inundation by ground water and collapse of karstic voids with inrush of mud and water into the excavation. The first problem is faced by lowering groundwater either through controlled drainage inside the tunnel or dewatering the ground by pumping at the ground surface, and grouting and reducing the rock mass permeability. Dewatering may have adverse effects, like: development of sinkholes, settlement at the ground surface due to soil consolidation, depletion of groundwater reservoirs which in turn may affect agriculture in the broader area, sea water intrusion at coastal zone, contamination of ground water, etc. Grouting, on the other hand is difficult in large voids and under high water head (Fig.1, 2).

In mines, dewatering is usually managed by massive pumping through deep wells to maintain huge cone of depression around each well, for, as long as the mine is under operation.

Confronting a karstic void during tunneling is really a challenge: it can be overcome by bridging or filling the void, if empty, by stabilizing with grouting its soft filling material, and tunneling through it afterwards, or by controlling mud and groundwater inrush by fore-boring, etc., before the tunnel face approaches the void (Marinos 2001, in Beck, et al, 2001).

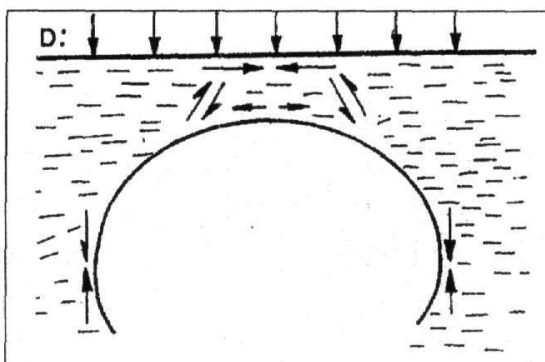

(a)

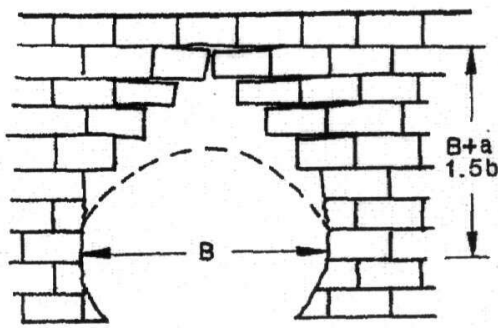

(b)

Figure 4. Stress and displacements in the rock surrounding a cavity, (a) Homogenous rock with thin cover-rock, and (b) Stratified hard rock (Sowers 1996) 


\section{PLANNING TO REDUCE RISK IN KARST SITES DEVELOPMENT}

The most economical approach in developing a site, underlain by karstified carbonate rock is to define the problem sites by site investigation and to plan location, size, and type of significant constructions out of the problem areas of the site. That means, if the aerial extent of the problem sites are known, it may be possible to place the most important structures in the safest part(s) of the construction site and leave the problem areas for non critical facilities such as golf courses, hiking trails, parking lots, parks, roadways, grass fields, etc.

Other means to minimize risk of structures over karst are (Fisher and Canace, 1989, Destephen and Warge 1992, Beck et al, 2001, 1999, 1995, etc.):

- To avoid (unlined) detention basins/ponds in the area, unless one wishes to use such basins for ground water recharge. This however is risky, since it will increase water head and flow rate and may be pollution, in the soil and rock.

- To design measures to maintain ground water level consistent with that prior to development

- $\quad$ To avoid ground grading, when possible, but if done it should reflect surface drainage away from the structures.

- To avoid placing utilities adjacent or beneath shallow foundations. If this is necessary place them in concrete duct bank.

- $\quad$ To provide water-tight storm drains and tie roof-drains directly into them.

- To seal pavement curbs and catch basins. Do not allow concentrated flows in unpaved or unlined ditches or swales (ponds).

- To use always lined retention basins and keep them away from the construction, if possible.

- To provide professional observation and inspection of site investigation, earthwork and foundation construction, so as to examine subsurface material and recommend changes in the initial design, aiming to reduce risk.

\section{CONCLUSIONS}

From the previous discussion it comes out that:

- Karst terrain is very complex to be grouped in classes and a difficult ground for construction of structures either on the ground surface or underground. It is a real challenge that can turn to a nightmare for engineers if the proper measures are not taken.

- Conventional methods of site investigation can be applied only to young karst with simple structure; for more mature karst none of these methods is $100 \%$ accurate. It demands more rigorous ground investigation by a multidisciplinary team that fully appreciates the complex characteristics of karst. Especially the location of underground voids is very difficult. No two karst sites are exactly alike in topography in geology and in structure.

- Risk assessment of the site should precede any design and the probability of future subsidence should be estimated.

- The design of engineering works on karst terrain, have to be adapted to the maturity of the karst.

- Various foundation alternatives such as spread footings on cover soil, with or without soil improvement, rigid mats and graded beams; deep foundations (piles or drilled piers); control of surface and ground waters and sinkhole development, etc., are practiced in karst. The kind of foundation applied is unique for each karst site and depends upon the maturity and the structure of the karst and the predicted foundation loading.

- The most dangerous sites for subsidence are those engaged to foundations over sinkholes. The controlling factors are: water percolating through the cover soil and overloading.

- The principal measures to be taken for avoiding subsidence are:

- To control of surface and ground water in the karst region.

- To avoid the ground overloading, and

- To place significant constructions out of the problem areas of the site. 
- In tunneling, problem areas can be located by fore-boring from the face of the tunnel.

In conclusions karst is a difficult ground for engineers and needs proper understanding for good engineering practice.
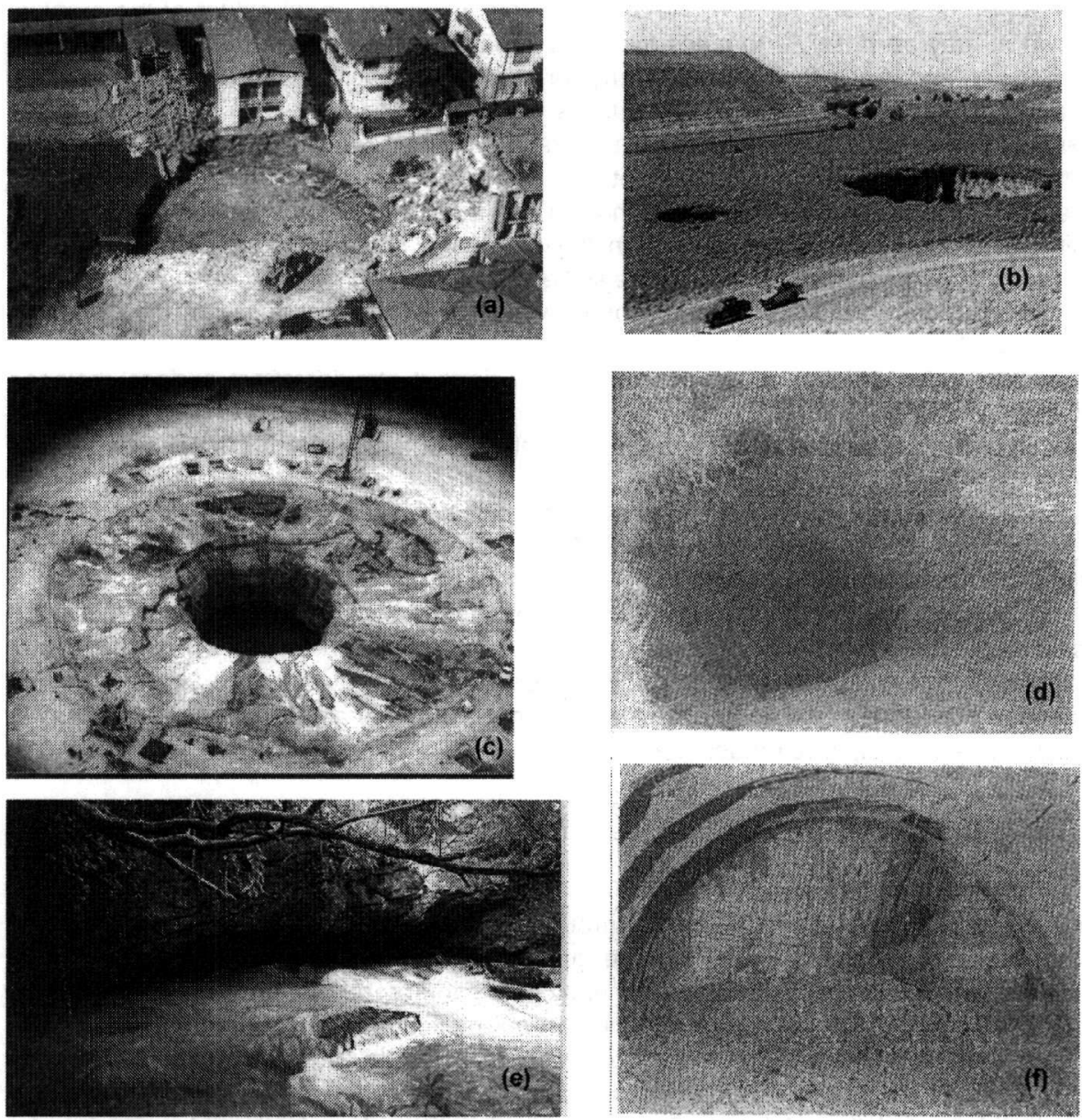

Figure 5. Examples of sinkholes collapse. (a) Sinkhole under repair in Camaiore, Toscany, Italy, 1995, diameter $30 \mathrm{~m}$, depth $13 \mathrm{~m}$; thikness of cover soil more than $100 \mathrm{~m}$. (in Beck et al, 2001, cover photo), (b) Sinkholes on the bottom of May Dam's lake, they drained the lakeTurkey (Ertunc, 2004), (c) Sinkhole collapse in Florida, USA, more than $130 \mathrm{~m}$ deep, ,(Fuleiham et al, 1997) (in Beck and Stephenson 1997, cover photo), (d) and (f) Sinkhole collapse over Dodoni tunnel, Epeiros, Greece, (Marinos 2001), (e) Cave and spring of Piges Aggiti river in marble, Drama, Greece. Behind the entrance there is a collapsed sinkhole.
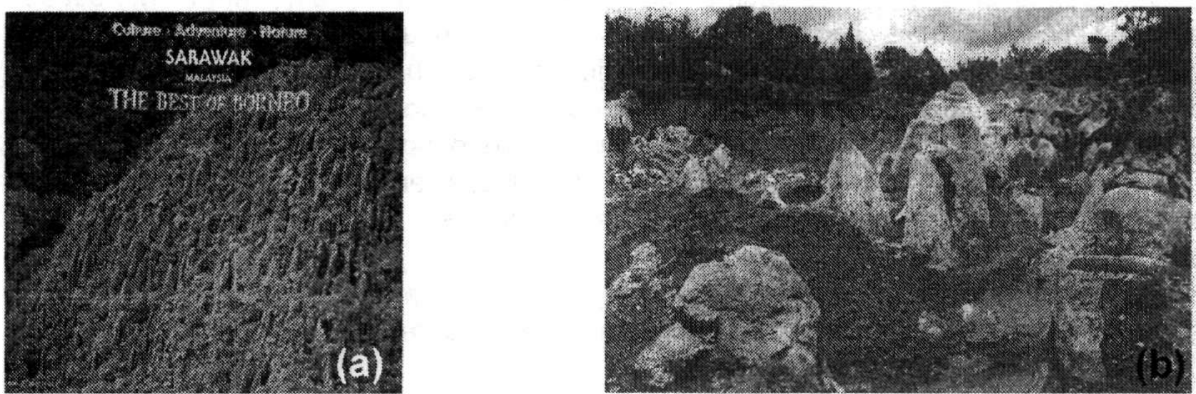

Figure 6 (a) and(b) Pinnacled karst terrain in tropics 


\section{REFERENCES}

Adams, A.L. 2001. A geoelectrical investigation of the freshwater aquifer near the well fields of north Andros Island, Bahamas. Proc. Conf. on "Geotechnical and Environmental Applications of Karst Geology and Hydrology. Beck, B.F. \& Herring, J.G. 2001 Balkema Publishers, pp. 341-346.

Beck, B.F. \& Herring, J.G. 2001. Geotechnical and Environmental Applications of Karst Geology and Hydrology Balkema Publishers, 438pp

Beck, B.F., Pettit, A.J. \& Herring J.G. 1999 (edrs). Hydrogeology and Engineering Geology of Sinkholes and Karst. Conference proceedings, Chapter 11, Special session on highway karst. Design, Construction and Repair. Balkema, Rotterdam, 478pp.

Beck, B.F. \& Stephenson J.B. 1997 (edrs). The Engineering Geology and Hydrogeology of Karst Terraines. Conference proceedings. Balkema, Rotterdam. 516pp.

Beck, B.F. \& Pearson, F.M. 1995 (edrs). Karst geohazards. Engineering and Environmental problems in Karst Terrane. Conference proceedings. Balkema, Rotterdam. 582pp

Beck, B.F. 1989 (editor). Engineering and Envirommental impacts of Sinkholes and Karst. Conference proceedings. Balkema, Rotterdam, 384pp.

Beck, B.F. \& Sinclair, W.C. 1986. Sinkholes in Florida: an introduction. Institute Report 85-86-4. Florida Sinkhole Research, USA.

Bennett, D. 1997. Finding a foothold. New Civil Engineer (4), 24-25.

Crawford, N. C. 2001. Field Trip Guide, Part I. Environmental problems associated with urban development upon karst, Bowling Green, Kentuky. Proc. Conf. on "Geotechnical and Environmental Applications of Karst Geology and Hydrology. Beck, B.F. \& Herring, J.G. 2001 Balkema Publishers, pp. 397-424.

Destephen, R.A. \& Wargo, R.H. 1992. Foundation Design in Karst Terrain. Bull. Assoc. Engng Geologists, vol. $X X I X(2), \mathrm{pp} .165-173$.

Ertunc, A. 2004. Karstic limestone problems of some dams in Turkey. Proc. $5^{\text {th }}$ Intern. Symposium on Eastern Mediterranean Geology. Thessaloniki, Greece, 14-20 April 2004.

Fischer, J.A. \& Canace, R. 1989. Foundation Engineering Construction in Karst Terrane. In "Foundation Engineering. Current Principles and Practices". Proc. Conf., Eveston, Illinois, ASCE, USA, 1989, pp. 29-42.

Fookes, P.G. 1997. Geology for engineers: the geological model, prediction and performance.Quarterly Journal of Engineering Geology, 30, 293-424.

Fookes, P.G. \& Hawkins, A.B. 1988. Limestone weathering: its engineering significance and a proposed classification scheme. Quarterly Journal of Engineering Geology, 21, 7-31.

Ford, D.C. \& Williams, P.F. 1989. Karst Geomorphology and Hydrology. Unwin Hyman, London.

Green, M.R., Forth, R.A. \& Beaumont, D. 1995. Land subsidence on Magnesian Limestone terrain in County Durham, England. International Association of Hydrological Sciences, 234, 423-431.

Hu, R.L., Yeung, M.R., Lee, C.F., Wang, S.S. \& Xiang, J.X. 2001. Regional risk assessment of karst collapse in Tangshan, China. Environmental Geology 2001, 40, pp. 1377-1389.

Jennings, J.E. 1966. Building on dolomites in the Transvaal. The Civil Engineer in South Africa,8, 41-62

Kannan, R. C. 1999. Designing foundations around sinkholes. Engineering Geology, 52, 75-82

Lowe, D. \& Waltham, T. 2002. Dictionary of karst and caves. British Cave Research Association Cave Studies, $10,1-40$.

Marinos P.G.. 2001.Tunnelling and mining in karstic terrane. An engineering challenge. Keynote Address. Proc. Conf. on "Geotechnical and Environmental Applications of Karst Geology and Hydrology. Beck, B.F. \& Herring, J.G. 2001 Balkema Publishers. Chapter 1., pp. 3-16.

Merrit, A.M. 1995. Geotecnical aspects of the design and construction of dams and pressure tunnels in soluble rocks. In Beck, B.F. \& Pearson, F.M. 1995 (edrs). Karst geohazards. Engineering and Environmental problems in Karst Terrane. Conference proceedings. Balkema, Rotterdam.

Reith, C.M., Cadden, A.W. \& Naples, C.J. 1999. Engineers challenged by Mother Nature's twist of geology, In: Beck, B.F., Pettit, A.J. \& Herring, J.G. (eds) Hydrology and Engineering Geology of Sinkholes and Karst. Balkema, Rotterdam, 149-155.

Sebela, S., Mihevc, A. \& Slabe, T. 1999. The vulnerability map of karst along highways in Slovenia. In: BECK, B.F., PETTIT, A.J. \& HERRING, J.G. (eds) Hydrology and Engineering Geology of Sinkholes and Karst. Balkema, Rotterdam, 419-422.

Sowers, G.F. 1996. Building on sinkholes. ASCE Press, USA, 202, pp.

Tharp, T.M. 1999. Mechanics of upward propagation of cover-collapse sinkholes. Engineering Geology, 52, 2333.

Thomas, B. \& Roth, M..J.S. 1999. Evaluation of site characterization methods for sinkholes in Pensylvania and New Jersey. Engineering Geology, 52, 1999, pp. 147-152.

Villard, P., Gourc, J.P. \& Giraud, H. 2000. A geosynthetic reinforcement solution to prevent the formation of localized sinkholes. Canadian Geotechnical Journal, 37, 987-999.

Wagener, F.v.M. 1985. Problems of soils in South Africa: dolomites. The Civil Engineer in South Africa, 27, 395407.

Waltham, A.C. \& Fookes, P.G. 2003. Engineering classification of karst ground conditions. Q.J Engng Geology and Hydrogeology, 36, pp. 101-118.

White, W.B. 2002. Karst Hydrology: recent development and open questions. Engineering Geology, 65, 2002, pp. 85-105.

Yilmaz, I. 2001. Gypsum/anhydrite: some engineering problems. Bull. Eng. Geol. Env. 2001, 59, pp. 227-230. 